\title{
Article
}

\section{Missed opportunities in health care education evidence synthesis}

Gordon, Morris, Vaz Carneiro, Antonio, Patricio, Madalena and Gibbs, Trevor

Available at http://clok.uclan.ac.uk/13587/

Gordon, Morris ORCID: 0000-0002-1216-5158, Vaz Carneiro, Antonio, Patricio, Madalena and Gibbs, Trevor (2014) Missed opportunities in health care education evidence synthesis. Medical Education, 48 . pp. 644-645. ISSN 0308-0110

It is advisable to refer to the publisher's version if you intend to cite from the work.

For more information about UCLan's research in this area go to

http://www.uclan.ac.uk/researchgroups/ and search for <name of research Group>.

For information about Research generally at UCLan please go to http://www.uclan.ac.uk/research/

All outputs in CLoK are protected by Intellectual Property Rights law, including Copyright law. Copyright, IPR and Moral Rights for the works on this site are retained by the individual authors and/or other copyright owners. Terms and conditions for use of this material are defined in the policies page.

\section{CLoK}

Central Lancashire online Knowledge www.clok.uclan.ac.uk

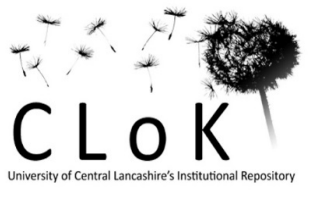




\title{
Missed opportunities in health care education evidence synthesis
}

\author{
Morris Gordon, ${ }^{1,2}$ Antonio Vaz Carneiro, ${ }^{3}$ Madaleno Patricio ${ }^{3}$ \& Trevor Gibbs ${ }^{4}$
}

Editor -We read with excitement the systematic review on how to teach evidence-based medicine (EBM) to medical trainees. ${ }^{1}$ The conclusions of the paper ${ }^{1}$ represent a concise and accurate reflection of this large synthesis of evidence. Unfortunately, we were left reflecting not on the evidence base illuminated by this review, but on the missed opportunities we will highlight herein. These examples are not in any way meant to represent a specific set of criticisms of this work, ${ }^{1}$ but, rather, are intended as exemplars of wider methodological issues that currently exist within much published material on the synthesis of evidence in health care education. ${ }^{2}$

In the course of introducing the problems of teaching the synthesis of evidence to medical trainees, the authors ${ }^{1}$ fail to mention any relevant conceptual framework or theoretical constructs. Such elements, even if they were to be highlighted with exemplars from other related disciplines such as education in primary research skills, would inform the reader and better situate the work. This is

\footnotetext{
${ }^{1}$ Department of Child Health, Blackpool Victoria Hospital, Blackpool, UK

${ }^{2}$ University of Central Lancashire, Preston, UK

${ }^{3}$ University of Lisbon, Lisbon, Portugal

${ }^{4}$ Association for Medical Education in Europe, Dundee, UK
}

Correspondence: Morris Gordon, Department of Paediatrics, Blackpool Victorial Hospital, Whinney Heys Road, Blackpool FY3 8NR, UK. Tel: 01253 303443;

E-mail: morris@betterprescribing.com

doi: $10.1111 /$ medu. 12478 a common problem; many very recently published examples from across the health education disciplines are similarly devoid of conceptual constructs. ${ }^{3-6}$

The stated aim of Ilic and Maloney's review ${ }^{1}$ is '[to] identify[ing] the most effective teaching for EBM'; thus, it represents what is known as a 'justification' review. ${ }^{7}$ This is not what its title, 'Methods of teaching medical trainees evidence-based medicine: a systematic review', ${ }^{1}$ conveys to the reader; rather, the title suggests a 'descriptive' review and a paradoxically far more interesting focus. As has been discussed within the pages of this very journal on countless occasions, primary education research that focuses on questions of 'whether' education is effective often ignores far more illuminating and useful questions, such as those of 'how', 'why', 'when' and 'what'. This shift in focus is now also reflected in evidence synthesis. ${ }^{2,8}$

The methodology of the study ${ }^{1}$ is clearly transparent, robust and well reported, and is consistent with the actual aims of the study. However, this does not necessarily equate to the best outcome for the reader. The decision to limit the studies included to randomised controlled trials certainly limits the amount of evidence, but does not necessarily enhance the strength of the conclusions, given the reach of the tapestry of evidence often on offer within the field. ${ }^{9}$ Additionally, it is not clear whether any attempts to collect data on the spe- cific interventions in order to allow replication or to contact authors for such data that were unavailable were made. It has recently been noted that whereas poor reporting of interventions in non-pharmacological trials is commonplace across disciplines, in the vast majority of cases authors will supply further details on request. ${ }^{10}$ Although contacting authors routinely might be considered a lofty standard for evidence synthesis, signposting for readers the extent to which the studies included did provide specific details of the courses in question would support readers who seek to replicate such works. ${ }^{11}$

This study ${ }^{1}$ is systematic, transparent and well communicated, and it succeeds in addressing the question of the effectiveness of education in EBM through a thorough synthesis of evidence. It is unfortunate that instances of such hard work within this and many other examples of systematic review items in education ${ }^{3-6}$ do not offer more to researchers and educators. Although consideration of the effectiveness of education is valid and important, far more illuminating opportunities exist in the synthesis of evidence. Such synthesis should consider delivering clarity to readers on the constituents of the education to which the evidence refers in order to facilitate the rapid replication of quality works and to more deeply clarify the answers to questions and thus to offer insight at a richer, conceptual 
level. Such forms of evidence synthesis may be more relevant to all involved and will support actual changes in educational practice and policy.

\section{REFERENCES}

1 Ilic D, Maloney S. Methods of teaching medical trainees evidence-based medicine: a systematic review. Med Educ 2014; 48:124-35.

2 Gordon M, Darbyshire D, Baker P. Separating the wheat from the chaff: the role of systematic review in medical education. Med Educ 2013;47:632.

3 Koole S, De Bruyn H. Contemporary undergraduate implant dentistry education: a systematic review. Eur J Dent Educ 2014;18:11-23.
4 Artemiou E, Adams CL, Towes L, Violato C, Coe JB. Informing webbased communication curricula in veterinary education: a systematic review of web-based methods used for teaching and assessing clinical communication in medical education. J Vet Med Educ 2014;41: 44-54.

5 Donnon T, Al Ansari A, Al Alawi $\mathrm{S}$, Violato $\mathrm{C}$. The reliability, validity, and feasibility of multisource feedback physician assessment: a systematic review. Acad Med 2014;89 (3): 115-6.

6 Levett-Jones T, Lapkin S. A systematic review of the effectiveness of simulation debriefing in health professional education. Nurse Educ Today 2013; doi: 10.1016/j.nedt.2013.09.020. [Epub ahead of print.]

7 Cook DA, Bordage G, Schmidt H. Description, justification, and clarification: a framework for classifying the purposes of research in medical education. Med Educ 2008;42:128-33.

8 Bearman M, Dawson P. Qualitative synthesis and systematic review in health professions education. Med Educ 2013;47:252-60.

9 Dornan T, Peile E, Spencer J. On 'evidence'. Med Educ 2008;42:232-3.

10 Hoffmann TC, Erueti C, Glasziou PP. Poor description of nonpharmacological interventions: analysis of consecutive sample of randomised trials. BMJ 2013;347: 3755 .

11 Gordon M, Darbyshire D, Saifuddin A, Vimalesvaran K. Limitations of poster presentations reporting educational innovations at a major international medical education conference. Med Educ Online 2013;18:1-4. 